\title{
CONSORT recommendations in abstracts of randomised, controlled trials on migraine and headache
}

\author{
Peer Carsten Tfelt-Hansen
}

Received: 5 May 2011/Accepted: 10 June 2011/Published online: 28 June 2011

(c) The Author(s) 2011. This article is published with open access at Springerlink.com

\begin{abstract}
A CONSORT statement on the content of abstracts of randomised, controlled trials (RCTs) was published in 2008. I therefore reviewed the abstracts from 2009 to 2010 published on RCTs in Cephalalgia, Headache and other (non-headache) journals. The following items were reviewed: number of patients, reporting of response either in percentages or absolute values, the use of $p$ values, and effect size with its precision. The latter was recommended in the CONSORT statement. A total of 46 abstracts were reviewed and effect size with $95 \%$ confidence intervals was only reported in seven abstracts. The influence of the CONSORT statement on reporting in abstracts has so far only had a limited influence on the headache literature.
\end{abstract}

Keywords CONSORT statement - Migraine - Treatment · Randomised · Clinical trials

"For clinical trials, clear, transparent, and sufficiently, detailed abstracts of journal articles and conference abstracts are important because readers often base their, assessment of a trial on such information" Hopewell et al. [1].

\section{Introduction}

As explained in the vignette, the abstract is an important part of the publication of a randomised, controlled trial

P. C. Tfelt-Hansen ( $\square)$

Department of Neurology, Danish Headache Center,

Glostrup Hospital, University of Copenhagen,

2000 Glostrup, Denmark

e-mail: ptha@glo.regionh.dk
(RCT). In 2008, the CONSORT group published a statement on reporting RCTs in journal and conference abstracts [1], see Table 1.

I therefore wanted to investigate whether this $\mathrm{CON}$ SORT statement has had an impact on the literature on RCTs in migraine and headache treatment. The years 2009 and 2010 were chosen as the appropriate years to evaluate this question. The CONSORT statement for abstract is very demanding (see Table 1) and I therefore chose to review only the most important efficacy items (in italics in Table 1).

\section{Methods}

The three headache journals, Cephalalgia, Headache and Journal of Headache and Pain, were hand-searched twice for RCTs in 2009 and 2010. In addition, PubMed was searched for RCTs in other journals in 2009 and 2010 with the search terms: "migraine", "treatment" and "clinical trial" as well as "headache", "treatment" and "clinical trial". The abstracts were rated for the presence of numbers in each treatment group or total number of patients, percentage response or absolute values for response, $p$ values, absolute effect size (percentage responding in active treatment group minus percentage responding in control group) and $95 \%$ confidence intervals $(95 \% \mathrm{CI})$ for absolute effect size (see Tables 2, 3 and 4).

\section{Results}

In Cephalalgia, 17 abstracts on RCTs (Table 2) [2-18] and in Headache 13 abstracts on RCTs were found (Table 3) [19-31]. In the Journal of Headache and Pain, only one 
Table 1 Items to include when reporting of randomised trials in journal or conference abstracts [1]

${ }^{\text {a }}$ For conference abstracts

Table 2 Presentation in abstracts concerning efficacy in double-blind, randomised, controlled trials (RCTs) in Cephalalgia in 2009 and 2010

\begin{tabular}{|c|c|}
\hline Item & Description \\
\hline Title & Identification of the study as randomised \\
\hline Authors $^{\mathrm{a}}$ & Contact details for the corresponding author \\
\hline Trial design & Description of the trial design (e.g. parallel, cluster, non-inferiority) \\
\hline \multicolumn{2}{|l|}{ Methods } \\
\hline Participants & Eligibility criteria for participants and the settings in which the data were collected \\
\hline Interventions & Interventions intended for each group \\
\hline Objective & Specific objective or hypothesis \\
\hline Outcome & Clearly defined primary outcome for this report \\
\hline Randomisation & How participants were allocated to interventions \\
\hline $\begin{array}{l}\text { Blinding } \\
\text { (masking) }\end{array}$ & $\begin{array}{l}\text { Whether or not participants, care givers and those assessing the outcomes were } \\
\text { blinded to group assignment }\end{array}$ \\
\hline \multicolumn{2}{|l|}{ Results } \\
\hline $\begin{array}{l}\text { Numbers } \\
\text { randomised }\end{array}$ & Number of participants randomised to each group \\
\hline Recruitment & Trial status \\
\hline $\begin{array}{l}\text { Numbers } \\
\text { analysed }\end{array}$ & Number of participants analysed in each group \\
\hline Outcome & $\begin{array}{l}\text { For the primary outcome, a result for each group and the estimated effect size and its } \\
\text { precision }\end{array}$ \\
\hline Harms & Important adverse events or side effects \\
\hline Conclusions & General interpretation of the results \\
\hline Trial registration & Registration number and name of trial register \\
\hline Funding & Source of funding \\
\hline
\end{tabular}

\begin{tabular}{|c|c|c|c|c|c|}
\hline References & $\begin{array}{l}\text { Numbers in each } \\
\text { group (total number } \\
\text { of patients) }\end{array}$ & $\begin{array}{l}\% \text { response or } \\
\text { absolute values (AV) }\end{array}$ & $p$ values & Effect size & $\begin{array}{l}95 \% \text { CI for } \\
\text { effect size }\end{array}$ \\
\hline \multicolumn{6}{|l|}{2010} \\
\hline$[2]$ & $37 / 37 / 38$ & - & - & - & - \\
\hline [3] & (1677) & - & + & - & - \\
\hline$[4]$ & $42 \mathrm{CO}$ & - & + & - & - \\
\hline [5] & $343 / 347$ & + & + & - & - \\
\hline [6] & $88 / 42$ & + & + & - & - \\
\hline [7] & (117) & + & + & - & - \\
\hline [8] & $30 \mathrm{CO}$ & $\mathrm{AV}$ & + & - & - \\
\hline [9] & $347 / 358$ & $\mathrm{AV}$ & + & - & - \\
\hline [10] & $341 / 338$ & $\mathrm{AV}$ & + & - & - \\
\hline [11] & (27) & - & - & - & - \\
\hline \multicolumn{6}{|l|}{2009} \\
\hline [12] & - & - & - & - & - \\
\hline [13] & (859) & + & - & - & - \\
\hline [14] & (410) & $\mathrm{AV}$ & + & - & - \\
\hline [15] & $(95)$ & $\mathrm{AV}$ & + & - & - \\
\hline [16] & $1135 / 846^{\mathrm{a}}$ & + & + & - & - \\
\hline [17] & $58 / 65$ & AV & + & + & + \\
\hline [18] & $40 \mathrm{CO}$ & $\mathrm{AV}$ & + & - & - \\
\hline
\end{tabular}


Table 3 Presentation in abstracts concerning efficacy in double-blind, RCTs in

Headache in 2009 and 2010

$\mathrm{CO}$ crossover

Table 4 Presentation in abstracts concerning efficacy in double-blind, RCTs in other (non-headache) journals in 2009 and 2010

$\mathrm{CO}$ crossover

${ }^{\text {a }}$ Mean and $95 \%$ CI for changes from baseline

\begin{tabular}{llllll}
\hline References & $\begin{array}{l}\text { Numbers in each } \\
\text { group (total number } \\
\text { of patients) }\end{array}$ & $\begin{array}{l}\text { \% response or } \\
\text { absolute values (AV) }\end{array}$ & $p$ values & $\begin{array}{l}\text { Effect } \\
\text { size }\end{array}$ & $\begin{array}{l}\text { 95\% CI for } \\
\text { effect size }\end{array}$
\end{tabular}

\begin{tabular}{clllll}
\hline 2010 & & & & & \\
{$[19]$} & $177 / 169$ & + & + & - & - \\
{$[20]$} & $688 / 696$ & $\mathrm{AV}$ & + & - & - \\
{$[21]$} & $99 / 96$ & + & + & - & - \\
{$[22]$} & $(52)$ & - & - & - & - \\
2009 & & & & & \\
{$[23]$} & $19 / 17$ & + & + & - & - \\
{$[24]$} & $(179)$ & $\mathrm{AV}$ & + & - & - \\
{$[25]$} & $153 / 153$ & + & + & - & - \\
{$[26]$} & $121 \mathrm{CO}$ & + & + & + & + \\
{$[27]$} & $(283)$ & $\mathrm{AV}$ & + & - & - \\
{$[28]$} & $(180)$ & + & + & - & - \\
{$[29]$} & $(69)$ & + & + & - & - \\
{$[30]$} & $(323)$ & + & + & - & - \\
{$[31]$} & $(60)$ & + & & - & - \\
\hline
\end{tabular}

\begin{tabular}{llllll}
\hline References & $\begin{array}{l}\text { Numbers in each } \\
\text { group (total number } \\
\text { of patients) }\end{array}$ & $\begin{array}{l}\text { \% response or } \\
\text { absolute values (AV) }\end{array}$ & $p$ values & $\begin{array}{l}\text { Effect } \\
\text { size }\end{array}$ & $\begin{array}{l}\text { 95\% CI for } \\
\text { effect size }\end{array}$ \\
\hline
\end{tabular}

\begin{tabular}{llllll}
\hline 2010 & & & & & \\
{$[33]$} & $133 \mathrm{CO}$ & $\mathrm{AV}$ & + & - & - \\
{$[34]$} & $46 \mathrm{CO}$ & $\mathrm{AV}$ & + & + & + \\
{$[35]$} & $53 / 55 / 55 / 65$ & $\mathrm{AV}$ & - & $+^{\mathrm{a}}$ & $+^{\mathrm{a}}$ \\
{$[36]$} & $(196)$ & $\mathrm{AV}$ & - & + & + \\
{$[37]$} & $82 / 82$ & + & + & + & + \\
{$[38]$} & $(66)$ & $\mathrm{AV}$ & - & + & + \\
{$[39]$} & $(265)$ & + & + & - & - \\
2009 & & & & & \\
{$[40]$} & $117 / 381 / 371 / 365$ & - & + & - & - \\
{$[41]$} & $29 / 49$ & $\mathrm{AV}$ & + & - & - \\
{$[42]$} & $(127)$ & $\mathrm{AV}$ & + & - & - \\
{$[43]$} & $31 \mathrm{CO}$ & + & - & - & - \\
{$[44]$} & $311 / 310$ & + & - & - & - \\
{$[45]$} & $172 / 159$ & $\mathrm{AV}$ & + & + & + \\
{$[46]$} & - & - & + & - & - \\
{$[47]$} & $35 / 35 / 33$ & + & - & - & - \\
{$[48]$} & $50 / 50$ & - & - & - & - \\
\hline & & - & & & \\
\hline
\end{tabular}

RCT was found (an RCT on deep brain stimulation in 11 patients with chronic cluster headache [31]). In the other (non-headache) journals, I found 16 abstracts of RCTs on headache and migraine [32-47].

The number of patients in each RCT varied from 27 to 1,981 with a median of 180 subjects. Percentage response or absolute values for response were reported in
35 of 46 abstracts (Tables 2, 3, 4) and $p$ values were reported in 33 of 43 abstracts (Tables 2, 3, 4). In contrast, effect size and its precision $(95 \% \mathrm{CI})$ were only reported in the abstract of one RCT in Cephalalgia [16] and Headache [25]. In other (non-headache) journals, effect size with 95\% CI was presented in five abstracts [34-37, 44] (Table 4). 


\section{Comments}

The number of patients treated in each RCT varied from relatively small crossover trials (minimum, $n=27$ trials [11] was, however, a parallel-group trial) to very large parallel-group trials (maximum, $n=1981$ ). The median was 180 patients, most likely a reasonable number.

In eight papers on RCTs, there was no mention in the abstract of response either in percentages or in absolute values $[2-4,12,22,40,46,48]$. Two of these abstracts were remarkable $[3,40]$. One was a very large RCT in which 1,677 patients were treated for $>1$ attack and 1,263 were treated for all 4 attacks [3]. Based on attack I data, telcagepant 140 and $280 \mathrm{mg}$ were significantly $(p<0.001)$ more effective than placebo for 2-h pain freedom and six other efficacy measures [3]. In the other RCT $(n=1,234)$ with different doses of telcagepant and placebo, only $p$ values $(p<0.001)$ were given [39]. These abstracts would not have been made much longer by reporting the responses, e.g. 24 and $25 \%$ 2-h pain freedom for telcagepant versus 10 and $11 \%$ pain freedom for placebo $[3,39]$.

$p$ values are traditionally used in reporting the results of RCTs and were used in most abstracts. These $p$ values can, however, be very small if in a very large RCT there is a small but clinically insignificant difference between two treatments. $p$ values can thus sometimes be misleading.

There is generally little reporting of effect size and its precision, which was only presented in seven abstracts [17, 26, 34, 36-38, 45]. Effect size (active minus control) in percentages or absolute value, with $95 \%$ confidence intervals (CI), is the clinically relevant measure. It is also useful in "negative" RCTs where 95\% CI (and not $p$ values) gives the precision of the comparability. Reporting of outcome measures in the abstracts of the 43 papers is thus not optimal when compared with the CONSORT statement for reporting in abstracts [1].

In the latest CONSORT statement from 2010, for efficacy measures with binary outcomes it is recommended that both absolute and relative effect sizes should be presented with an estimate of the precision such as $95 \%$ CI $[48,49]$. The relative risk (active/placebo) is $1.5(25 \% /$ $10 \%$ ) for pain freedom at $2 \mathrm{~h}$ for telcagepant $280 \mathrm{mg}$ and the odds ratio is 3.0 [3]. Relative risk and odds ratio [2] are thus difficult to judge clinically. One should be content with reporting effect size and its precision in abstracts of RCTs on migraine and headache. For example, the effect size for telcagepant $280 \mathrm{mg}$ for pain freedom at $2 \mathrm{~h}$ should be reported as 15 with $95 \%$ CI: $10-19 \%$ [3].

In conclusion, the CONSORT statement from 2008 on reporting RCT in abstracts [1] has only had a minor impact on the headache literature in 2009 and 2010.

\section{Conflict of interest None.}

Open Access This article is distributed under the terms of the Creative Commons Attribution License which permits any use, distribution and reproduction in any medium, provided the original author(s) and source are credited.

\section{References}

1. Hopewell S, Clarke M, Moher D, Wager E, Middleton P, Altman DG, Schulz KF et al (2008) CONSORT for reporting randomised trials in journal and conference abstracts. Lancet 371:281283

2. Høivik HO, Laurijssens BE, Harnisch LO, Twomey CK, Dixon RM, Kirkham JT et al (2010) Lack of efficacy of the selective iNOS inhibitor GW274150 in prophylaxis of migraine headache. Cephalalgia 30:1458-1467

3. Ho AP, Dahlöf CGH, Silberstein SD, Saper JR, Ashina M, Kost JT et al (2010) Randomized, controlled trial of telcagepant over four migraine attacks. Cephalalgia 30:1443-1457

4. Bruijn J, Duirenvoorden H, Passchier J, Locher H, Dijsstra N, Arts W-F et al (2010) Medium-dose riboflavin as a prophylactic agent in children with migraine: a preliminary placebo-controlled, randomised, double-blind, cross-over trial. Cephalalgia 30:1426-1434

5. Lipton RB, Grosberg B, Singer RP, Pearlman SH, Sorrentino JV, Quiring JN et al (2010) Efficacy and tolerability of a new powered formulation of diclofenac potassium for oral solution for the acute treatment of migraine: results from the International Migraine Pain Assessment Clinical Trial (IMPACT). Cephalalgia 30:1336-1345

6. Ferrari MD, Färkkilä M, Reuter U, Pilgrim A, Davis C, Krauss M et al (2010) Acute treatment of migraine with the selective 5-HT1F receptor agonist lasmiditan - a randomized proof-ofconcept trial. Cephalalgia 30:1170-1178

7. Djupesland PG, Docekal P, Czech Migraine Investors Group. Intranasal sumatriptan powder delivered by a novel breath-activated bi-directional device for the acute treatment of migraine: a randomized, placebo-controlled study. Cephalalgia 30:933-942

8. Alpay K, Ertas M, Orhan EK, Üstay DK, Lieners C, Baykan B et al (2010) Diet restriction in migraine, based on $\operatorname{IgG}$ against food: a clinical double-blind, randomized, crossover, trial. Cephalalgia 30:829-837

9. Diener HC, Dodick DW, Aurora SK, Turkel CC, DeGryse RE, Lipton RB et al (2010) OnabotulinumtoxinA for treatment of chronic migraine. Results from the double-blind, randomized, placebo-controlled phase of the PREEMPT 2 trial. Cephalalgia 30:804-814

10. Aurora SK, Dodick DW, Turkel CC, DeGryse RE, Silberstein SD, Lipton RB et al (2010) OnabotulinumtoxinA for treatment of chronic migraine. Results from the double-blind, randomized, placebo-controlled phase of the PREEMPT 1 trial. Cephalalgia 30:793-803

11. Teerpker M, Hötzel J, Timmesfeld N, Reis J, Mylius V, Haag A et al (2010) Low-frequency rTMS of the vertex in the prophylactic treatment of migraine. Cephalalgia 30:137-144

12. Dahlöf CG, Hauge AW, Olesen J (2009) Efficacy and safety of tonabersat, a gap-junction modulator, in the acute treatment of migraine, a double-blind, parallel-group randomized study. Cephalalgia 29(Suppl 2):7-16

13. Silberstein SD, Schoenen J, Göbel H, Diener HC, Elkind AH, Klapper JA et al (2009) Tonabersat, a gap-junction modulator: efficacy and safety in two randomized, placebo-controlled, doseranging studies of acute migraine. Cephalalgia 29(Suppl 2):17-27

14. Brandes JL, Poole A, Kallela M, Scheiber CP, MacGregor EA, Silberstein SD et al (2009) Short-term frovatriptan for the 
prevention of difficult-to-treat menstrual migraine attacks. Cephalalgia 29:1133-1148

15. Diener HC, Gendolia A, Feursenger A, Evers S, Straube A, Schumacher H (2009) Telmisartan in migraine prophylaxis: a randomized, placebo-controlled trial. Cephalalgia 29:921-927

16. Lipton RB, Dodick DW, Adelman JU, Kaniecki RG, Lener SE, White JD, Nelsen AC (2009) Consistency of response to sumatriptan/naproxen sodium in a placebo-controlled, crossover study. Cephalalgia 29:826-836

17. Goadsby PJ, Ferrari MD, Csanyi A, Olesen J (2009) Mills: Tonabersat TON-01-05 Study Group. Randomized, double-blind, placebo-controlled, proof-of-concept study of the cortical spreading depression agent tonabersat in migraine prophylaxis. Cephalalgia 29:742-750

18. Lindelof K, Bendtsen L (2009) Memantine for prophylaxis of chronic tension-type headache. A double-blind, randomized, crossover clinical trial. Cephalalgia 29:314-321

19. Prior MJ, Codispoti JR, Fu M (2010) A randomized, placebocontrolled trial of acetaminophen for treatment of migraine headache. Headache 50:819-833

20. Dodick DW, Turkel CC, DeGryse RE, Aurora SK, Silberstein SD, Lipton RB et al (2010) OnabotulinumtoxinA for treatment of chronic migraine: pooled results from the double-blind, randomized, placebo-controlled phases of the PREEMPT clinical program. Headache 50:921-936

21. Drescher MJ, Alpert EA, Zalut T, Torgovicky R, Wimpfheimer Z (2010) Prophylactic etoricoxib preventing Yom Kippur headache: a placebo-controlled double-blind and randomized trial of prophylaxis for ritual fasting headache. Headache 50:1328-1334

22. Borusiak P, Biederman H, Bosserhoff A, OppJ et al (2010) Lack of efficacy of manual therapy in children and adolescents with suspected cervicogenic headache: results of a prospective, randomized, placebo-controlled and blinded trial. Headache 50: 224-231

23. Mathew NT, Jaffri SF (2009) A double-blind comparison of onabotulinumtoxinA (BOTOX) and topiramate (TOPAMAX) for the prophylactic treatment of chronic migraine: a pilot study. Headache 49:1466-1478

24. Silberstein SD, Berner T, Tobin J, Xiang Q, Campbell JC (2009) Scheduled short-term prevention with frovatriptan for migraine occurring exclusively in association with menstruation. Headache 49:1283-1297

25. Silberstein SD, Lipton RB, Dodick D, Freitag F, Mathew NT, Brandes J et al (2009) Topiramate treatment of chronic migraine, a randomized placebo-controlled trial of quality of life and other measures. Headache 49:1153-1162

26. Hedlund C, Rapoport AM, Dodick DW, Goadsby PJ (2009) Zolmitriptan nasal spray in the acute treatment of cluster headache. A meta-analysis of two studies. Headache 49:1315-1323

27. Mathew NT, Landy S, Strak S, Tietjen GE, Derosier FJ, White J et al (2009) Fixed-dose sumatriptan and naproxen in poor responders to triptans with a short half-life. Headache 49:971-982

28. Li Y, Liang F, Xang X, Tian X, Yan J, Sun G et al (2009) Acupuncture for treating acute attacks of migraine: a randomized controlled trial. Headache 49:805-816

29. Aurora SK, Rozen TD, Kori SH, Shrewbury SB (2009) A randomized, double-blind, placebo-controlled study of MAP0004 in adult patients with migraine. Headache 49:826-837

30. Cady RK, Mathew N, Diener HC, Hu P, Haas M, Novak GP, Study Group (2009) Evaluation of carisbamate for the treatment of migraine in a randomized, double-blind trial. Headache 49: 216-226

31. Cady RK, Martin VT, Geraud G, Rodgers A, Zhang Y, Ho AP et al. Rizatriptan 10-mg ODT for early treatment of migraine and impact of migraine education on treatment of response. Headache 2009;49:687-686
32. Fontaine D, Lazorthes Y, Martens P, Blond S, Geraud G et al (2010) Safety and efficacy of deep brain stimulation in refractory cluster headache: a randomized placebo-controlled double-blind trial followed by a 1-year open extension. J Headache Pain 11: 23-31

33. Tullo V, Allais G, Ferrari MD, Curone M, Mea E, Omboni S et al (2010) Frovatriptan versus zolmitriptan for the acute treatment of migraine: a double-blind, multicenter, randomized, Italian study. Neurol Sci 31(Suppl 1):S115-S119

34. Alstadhaug KB, Odeh F, Salvesen R, Bekkelund SI (2010) Prophylaxis of migraine with melatonin: a randomised controlled trial. Neurology 75:1527-1532

35. Holroyd KA, Cottrell CK, O'Donnell, Cordingley GE, Drew JB, Carlson BW et al. Effect of preventive (beta blocker) treatment, behavioural migraine management, or their combination on outcomes of optimized acute treatment in frequent migraine: randomized controlled trial. BMJ 2010;341 (in press)

36. Friedman BW, Solorzano C, Esses D, Xia S, Hochberg M, Dua N et al (2010) Treating headache recurrence after emergency department discharge: a randomized, controlled trial of naproxen versus sumatriptan. Ann Emerg Med 56:7-17

37. Lipton RB, Dodick DW, Silberstein SD, Saper JR, Aurora SK, Pearlman SH et al (2010) Single-pulse transcranial magnetic stimulation for acute migraine with aura: a randomized, doubleblind parallel-group sham-controlled trial. Lancet Neurol 9: 373-380

38. Kostic MA, Gutierrez FJ, Rieg TS, Moore TS, Gendron RT (2010) A prospective, randomized trial of intravenous prochlorperazine versus subcutaneous sumatriptan in acute migraine therapy in the emergency department. Ann Emerg Med 56: $1-6$

39. Gertsch JH, Lipman GS, Holch PS, Merritt A, Mulcahy A, Fisher RS et al (2010) Prospective, double-blind, randomized, placebocontrolled comparison of acetazolamide versus ibuprofen for prophylaxis against high altitude headache: the Headache Evaluation of Altitude Trial (HEAT). Wilderness Environ Med 21:236-243

40. Connor KM, Shapiro RE, Diener HC, Lucas S, Kost J, Fan X et al (2009) Randomized, controlled trial of telcagepant for the acute treatment of migraine. Neurology 73:970-977

41. Guyuron B, Reed D, Kriegler JS, Davis J, Pahmini N, Amini S (2009) A placebo-controlled surgical trial of migraine headaches. Plast Reconstr Surg 124:461-468

42. Petri S, Tölle T, Straube A, Pfaffenrath V, Stefenelli U, CeballosBauman A (2009) Dysport Migraine Study Group. Botulinum toxin as preventive treatment for migraine: a randomized doubleblind study. Eur Neurol 62:204-211

43. Hauge AW, Ashgar MS, Schytz HW, Chistensen K, Olesen J (2009) Effects of tonabersat on migraine with aura: a randomized, double-blind, placebo-controlled crossover study. Lancet Neurol 8:718-723

44. Mannix LK, Martin VT, Cady RK, Diamond ML, Lener SE, White JD et al (2009) Combination treatment for menstrual migraine and dysmenorrheal using sumatriptan-naproxen: two randomized controlled trials. Obstet Gynecol 114:106-113

45. Dodick DW, Freitag F, Banks J, Saper J, Xiang J, Rupnow M et al (2009) CAPSS-277 Investigator Group. Topiramate versus amitriptyline in migraine prevention: a 26-weeks, multicenter, randomized, double-blind, double-dummy, parallel-group noninferiority trial in adult migraineurs. Clin Ther 31:542-559

46. Miller MA, Levsky ME, Enslow W, Rosin A (2009) Randomized evaluation of octreotide vs prochlorperazine for ED treatment of migraine headache. Am J Emerg Med 27:160-164

47. Lewis D, Winter P, Saper J, Ness S, Polverejan E, Wang S et al (2009) Randomized, double-blind, placebo-controlled study to evaluate the efficacy and safety of topiramate for migraine 
prevention in pediatric subjects 12 to 17 years of age. Pediatrics 123:924-934

48. Millán-Guerrero RO, Isais-Millán S, Baretto-Vizcairo S, RiveraCastano L, Rios-Madariaga C (2009) Subcutaneous histamine versus botulinum toxin type $\mathrm{A}$ in migraine prophylaxis: a randomized, double-blind study. Eur J Neurol 16:88-94
49. Schulz KF, Altman DG, Mosher D, For the CONSORT Group (2010) CONSORT 2010 statement: updated guidelines for reporting parallel group randomised trials. J Clin Epidemiol 63:834-840 